\title{
Validitas Modul Tutorial Gambar Teknik dan Listrik dengan Autocad
}

\author{
Hamdani ${ }^{*}$, Doni Tri Putra Yanto ${ }^{1}$, dan Ricky Maulana ${ }^{1}$ \\ ${ }^{1}$ Jurusan Teknik Elektro, Fakultas Teknik, Universitas Negeri Padang \\ ${ }^{*}$ Corresponding author, e-mail: hamdani@ft.unp.ac.id
}

\begin{abstract}
Abstrak-Gambar Teknik dan Listrik merupakan salah satu mata kuliah wajib yang harus dipelajari oleh mahasiswa . Dalam pelaksanaan pembelajaran mata kuliah ini masih dilakukan secara manual yaitu menggunakan pensil dan kertas gambar. Namun era komputerisasi sekarang pembelajaran Gambar Teknik dan Listrik perlu diimbangi dengan kemajuan zaman. Salah satunya menggunakan software AutoCAD dalam menyelesaikan materi gambar yang ada. Oleh karena itu, butuh pengembangan bahan ajar modul dengan tutorial bisa membantu untuk memahami penggunaan software dalam menyelesaikan materi. Penelitian ini bertujuan untuk mengetahui validitas modul tutorial Gambar dan Teknik dengan AutoCAD yang telah dikembangkan. Data penelitian diperoleh dari analisis angket uji validitas oleh validator yang terdiri 2 orang ahli materi dan media. Hasil uji validitas modul tutorial AutoCAD yang dinilai validator memperoleh nilai rata -rata 111 untuk ahli materi pada kategori valid sedangkan untuk ahli media mencapai nilai rata rata skor 120 dengan kategori sangat valid.
\end{abstract}

Kata Kunci : Validitas, Modul AutoCAD, Gambar Teknik dan Listrik, Pembelajaran

\begin{abstract}
Mechanical and Electrical Images is one of the compulsory subjects that students must learn. In the implementation of learning this course is still done manually, using pencil and drawing paper. But the computerized era now learning Engineering and Electrical Images needs to be balanced with the progress of the times. One of them uses AutoCAD software in completing existing image material. Therefore, the need to develop module teaching materials with tutorials can help to understand the use of software in completing material. This study aims to determine the validity of the Image and Engineering tutorial module with AutoCAD that has been developed. The research data obtained from the questionnaire validity test analysis by the validator consisting of 2 material and media experts. The results of the validity test of the AutoCAD tutorial module rated by the validator obtained an average score of 111 for the material expert in the valid category while the media expert achieved an average score of 120 with a very valid category.
\end{abstract}

Keywords : Validity, AutoCAD Modules, Engineering and Electrical Images, Learning

This is an open access article distributed under the Creative Commons 4.0 Attribution License

\section{Pendahuluan}

Kemajuan teknologi dan informasi turut dirasakan oleh institusi pendidikan pada saat ini. Proses belajar yang dahulunya dilakukan secara monoton dan searah (teaching centered) sekarang berubah menjadi student centered yang merupakan salah satu cara membantu mahasiswa untuk lebih aktif dan dinamis dalam mencari serta mengembangkan nalar dalam mengelola sumber informasi, salah satu berkaitan dengan materi pembelajaran [1]. Hal ini membutuhkan pengembangan sehingga tujuan pembelajaran dapat tercapai.
Salah satu cara pengembangan yang dilakukan adalah bahan ajar dalam mata kuliah Gambar Teknik dan Listrik bertujuan supaya mahasiswa memperoleh keahlian dalam pembuatan gambar kerja sebagai dasar perencanaan baik gambar teknik ataupun gambar listrik. Di era komputerisasi ini dosen sebagai instruktur dalam mata kuliah Gambar Teknik dan Listrik yang merupakan salah satu mata kuliah dasar keahlian yang wajib diikuti oleh mahasiswa Teknik Elektro bergeser dari gambar teknik dan listrik yang dibuat manual menggunakan pensil dan kertas gambar menjadi proses gambar berbasis komputer atau 
memiliki keterampilan menggunakan aplikasi AutoCAD dalam membimbing mahasiswanya selama proses pembelajaran. Penerapan pembelajaran yang berbasis komputer ini akan menjadi efektif jika diterapkan dengan sistem student centre learning. Dampak dari keadaan tersebut adalah setiap mahasiswa dapat mengaplikasikan dan membuat gambar perencanaan di bidang kelistrikan (single line, wiring, dsb), tidak hanya selama perkuliahan melainkan sampai setelah tamat dan setelah berada di Dunia Usaha/ Dunia Industri (DU/DI) karena dengan menggunakan aplikasi tersebut pekerjaan menggambar menjadi lebih cepat dan efektif.

Oleh karena itu, untuk meningkatkan pengetahuan dan keterampilan perencanaan yang dimulai dari membuat gambar perencanaan di bidang Teknik Listrik sampai pada penerapan yang memiliki kerapian dan estetika, setiap mahasiswa harus memiliki keahlian dasar dalam Gambar Teknik dan Listrik. Dalam pelaksanaan pembelajaran mata kuliah Gambar dan Teknik ini dibutuhkan perangkat pembelajaran yang dapat dijadikan panduan atau sumber belajar bagi pengampu mata kuliah. Salah satu sumber belajar yang dapat digunakan oleh mahasiswa adalah modul yang bisa menjadi sarana pembelajaran dalam bentuk tulis yang bisa dirancang untuk memberikan stimulus untuk mahasiswa agar lebih mudah mencapai tujuan pembelajaran. Media ini juga diharapkan menarik perhatian dan memberikan pemahaman lebih mendalam kepada mahasiswa untuk mempelajari Gambar Teknik dan Listrik. Salah satu inovasi yang dapat dilakukan adalah dengan mengajarkan teknik menggambar yang digunakan dalam menggambar menggunakan aplikasi AutoCAD. Aplikasi ini lebih efektif dan efisien yang mana bertujuan untuk membekali mahasiswa dalam menggambar sesuai dengan ukuran yang diatur sesuai dengan ketentuan sehingga gambar yang dihasilkan dapat presisi dan mudah untuk diubah [2].

Jadi pembelajaran dan materi yang baik sangat diperlukan untuk menyiapkan mahasiswa memiliki keterampilan menggambar dengan menggunakan modul dalam bentuk tutorial AutoCAD [3]. Sehingga dalam menjalankan program AutoCAD mahasiswa diajarkan untuk memahami perintah command line yang disajikan dalam bahasa inggris secara bertahap yang pada akhirnya dapat merancang gambar dengan baik [4].

Modul adalah salah satu bentuk bahan ajar berisi tentang semua komponen dasar bahan ajar yang terencana dikemas secara utuh dan sistematis yang didesain untuk membantu mahasiswa menguasai tujuan pembelajaran dan juga menarik perhatian mahasiswa dalam belajar[5][6]. Modul memuat tujuan pembelajaran, materi serta evaluasi, Bahan ajar ini memandu mahassiwa sebagai pembelajar aktif dalam mengikuti pembelajaran dengan materi setiap BAB yang berurutan dan berkaitan kemudian dilengkapi dengan evaluasi yang dapat dikerjakan mandiri. Selain itu, dosen sebagai pengampu mata kuliah perlu mengarahkan mahasiswa melalui proses pembelajaran sehingga nantinya bisa menerapkan pengetahuan yang didapat dalam kehidupan sehari hari [7]. Modul ini diharapkan dapat meningkatkan kreativitas dan berfungsi sebagai sarana belajar yang bersifat mandiri serta belajar sesuai dengan kecepatan masing-masing [8]. Modul digunakan untuk memudahkan mahasiswa belajar dimana saja dan kapan saja, sehingga tidak terbatas ruang dan waktu.

Oleh karena itu, untuk mengatasi masalah yang ada dalam pembelajaran tersebut diupayakan modul tutorial Gambar Teknik dan Listrik dengan aplikasi AutoCAD yang valid. Valid berdasarkan kebutuhan mahasiswa yang dapat membangun dan menyusun pengetahuan serta keterampilan. Berdasarkan latar belakang diatas, maka dirumuskan masalah yaitu "Bagaimanakah uji validitas modul tutorial Gambar Teknik dan Listrik dengan aplikasi AutoCAD?

\section{Metode Penelitian}

Metoda penelitian yang dilakukan adalah pengembangan yang dikembangakan oleh Sugiyono yang terdiri dari 10 tahap yaitu 1) Mencari potensi dan masalah, 2) Pengumpulan informasi, 3) Desain produk, 4) Validasi desain, 5) Revisi produk, 6) Uji coba produk, 7) Revisi produk, 8) Uji coba pemakaian, 9) Revisi produk, 10) Produksi produk. Validasi modul merupakan salah satu tahap validasi desain. Validasi modul dilakukan oleh validator. Validitas ini untuk menguji ketepatan item yang telah dibuat berdasarkan isi, konstruksi dan kebahasaan modul tutorial berdasarkan penilaian pakar/validator [9] [10].

Berdasarkan teknik pengumpulan data, analisa yang digunakan dalam penelitian ini menggunakan teknik analisis deskriptif kuantitatif Instrument digunakan untuk mengukur nilai variabel yang akan diteliti. Untuk mendapatkan data yang akurat maka ada metode dari Likert. Skala likert tersaji pada tabel dibawah ini 
Tabel 1. Skala Likert

\begin{tabular}{|l|l|l|}
\hline No & Kategori & Skor \\
\hline 1 & Sangat Setuju & 5 \\
\hline 2 & Setuju & 4 \\
\hline 3 & Cukup & 3 \\
\hline 4 & Kurang Setuju & 2 \\
\hline 5 & Tidak Setuju & 1 \\
\hline
\end{tabular}

Diadaptasi dari [8]

Skor yang diperoleh dari ahli media dan materi kemudian dikonversikan menjadi empat skala kategori. Pada dasarnya data kuantitatif dari tiap item instrument dihitung dengan menggunakan teknik analisis nilai rata - rata kemudian untuk mengetahui peringkat terakhir untuk setiap item, jumlah nilai dibagi dengan banyaknya responden yang menjawab angket tersebut [8]. Teknik analisis data yang digunakan adalah dengan memproses angka hasil pengukuran dari data angket. Data angket diperoleh dari ahli materi dan ahli media dalam mata kuliah Gambar Teknik dan Listrik. Berikut langkah yang digunakan untuk menganalisis data yaitu menghitung rata - rata, mengubah skor rata -rata menjadi data kualitatif, dan skor rata rata yang diperoleh diubah ke dalam kriteria kualitatif. Tabel dibawah ini merupakan pedoman pengkonversian.

Tabel 2. Validitas dari Ahli Media dan Materi

\begin{tabular}{|l|l|l|}
\hline No & Rentangan Skor & Kategori \\
\hline 1 & $\mathrm{X}>\mathrm{Mi}+1.8 \mathrm{Sbi}$ & $\begin{array}{l}\text { Sangat } \\
\text { Valid }\end{array}$ \\
\hline 2 & $\begin{array}{l}\mathrm{Mi}+0.6 \mathrm{SBi}<\mathrm{X} \leq \mathrm{Mi}+1.8 \\
\mathrm{Sbi}\end{array}$ & Valid \\
\hline 3 & $\begin{array}{l}\mathrm{Mi}-0,6 \mathrm{SBi}<\mathrm{X} \leq \mathrm{Mi}+0,6 \\
\mathrm{Sbi}\end{array}$ & $\begin{array}{l}\text { Cukup } \\
\text { Valid }\end{array}$ \\
\hline 4 & $\mathrm{Mi}-1,8 \mathrm{SBi}<\mathrm{X} \leq \mathrm{Mi}-0,6 \mathrm{Sbi}$ & Kurang \\
\hline 5 & $\mathrm{X} \leq \mathrm{Mi}-1,8 \mathrm{Sbi}$ & $\begin{array}{l}\text { Tidak } \\
\text { Valid }\end{array}$ \\
\hline
\end{tabular}

Sumber : [8]

Rata-rata ideal (Mi) dan simpangan baku (SBi) diperoleh dengan menggunakan rumus sebagai berikut:

$$
\begin{aligned}
& \mathrm{Mi}=1 / 2(\text { skor tertinggi }+ \text { skor terendah }) \\
& \mathrm{SBI}=\left(\frac{1}{2}\right)\left(\frac{1}{3}\right)(\text { Skor maks }- \text { skor min) }
\end{aligned}
$$

Keterangan:

$$
\begin{aligned}
& \text { X Jumlah skor yang diperoleh dari uji } \\
& \text { validasi } \\
& \text { Mi : Rata rata ideal }
\end{aligned}
$$

Sbi : Simpangan baku ideal

Skor kategori pada tabel di atas akan dijadikan acuan terhadap hasil evaluasi ahli dan pengguna/mahasiswa. Hasil tersebut kemudian menunjukkan tingkat valid dari modul tutorial AutoCAD yang dikembangkan

Pemberian nilai keprakstisan dengan cara:

$$
\begin{aligned}
& P=\frac{x}{Y} \times 100 \% \\
& \text { Keterangan: } \\
& \mathrm{P}=\text { Nilai Praktikalitas } \\
& \mathrm{X}=\text { Skor yang diperoleh } \\
& \mathrm{Y}=\text { Skor Maksimum }
\end{aligned}
$$

Dengan kategori pencapaian responden digunakan klasifikasi. Seperti pada Tabel 3

Tabel 3. Kategori Kepraktisan Modul

\begin{tabular}{ccc}
\hline No & $\begin{array}{c}\text { Tingkat } \\
\text { Pencapaian } \\
(\%)\end{array}$ & Kategori \\
\hline 1 & $90-100$ & Sangat Praktis \\
\hline 2 & $80-89$ & Praktis \\
\hline 3 & $65-79$ & Cukup Praktis \\
\hline 4 & $55-64$ & Kurang Praktis \\
\hline 5 & $0-54$ & Tidak Praktis \\
\hline Sumber $[11]$ &
\end{tabular}

\section{HaSil dan PEMbahasan}

Analisis data merupakan bagian yang menyajikan tentang hasil analisis dari data-data yang diperoleh selama melakukan penelitian dan pengembangan. Analisis data ditujukan untuk menjawab pertanyaan dari penelitian. Alat pengumpul data berupa angket dengan empat pilihan jawaban untuk ahli dan lima pilihan jawaban untuk mahasiswa. Berikut adalah hasil dari analisis tersebut:

\section{A. Analisis Data Ahli Materi}

Materi merupakan suatu aspek yang pokok dalam sebuah modul pembelajaran. Baik dan tidaknya penyusunan materi dapat mempengaruhi proses dan hasil dari kegiatan belajar mengajar. Ahli materi membaca dan memahami kemudian memberikan penilaian terhadap modul dalam sebuah angket. Data hasil penilaian modul pembelajaran pada aspek materi dikonversikan ke dalam interval skor skala lima. Angket untuk ahli materi terdapat 35 butir soal, maka dapat diketahui 
bahwa nilai skor maksimum adalah 140 , total skor minimum adalah 35 dengan simpangan baku ideal adalah 18 Nilai tersebut maka jika dikonversikan kedalam sebuah tabel 6 kategori kelayakan hasilnya adalah sebagai berikut.

Tabel 3. Konversi Skor Rata -Rata Untuk Ahli Materi

\begin{tabular}{|l|l|l|}
\hline No & Rentangan Skor & Kategori \\
\hline 1 & $\mathrm{X}>119$ & Sangat Valid \\
\hline 2 & $98<\mathrm{X} \leq 119$ & Valid \\
\hline 3 & $77<\mathrm{X} \leq 98$ & Cukup Valid \\
\hline 4 & $56<\mathrm{X} \leq 77$ & Kurang \\
\hline 5 & $\mathrm{X} \leq 56$ & Tidak Valid \\
\hline
\end{tabular}

Dari tabel diatas, penilaian ahli materi tentang modul pembelajaran berada dalam kategori valid yaitu dengan rata rata total skor yang didapatkan yaitu 111.

Penilaian data ahli materi meliputi indikator Self instruction, self contained, stand alone, adaptive, dan user friendly. Perhitungan distribusi frekuensi menghasilkan kategori valid dengan rata rata skor 111. Persentase untuk setiap indikator dapat dilihat pada tabel dibawah ini.

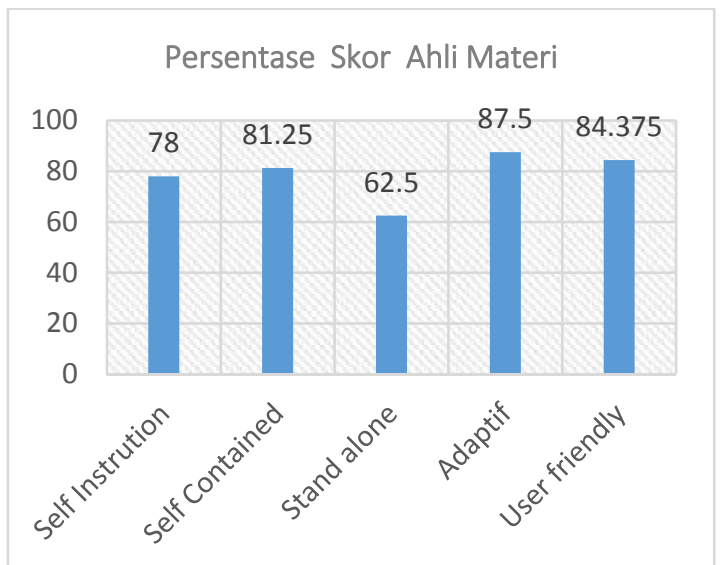

Gambar 1. Histogram Persentase Skor Ahli Materi

Dari hitogram diatas, terlihat persentase untuk masing masing aspek dari angket yang diberikan kepada ahli materi, Untuk indikator adaptif memperoleh persentase tertinggi yaitu $87.5 \%$, kemudian disusul oleh indikator user friendly memiliki persentase $84.375 \%$ yang tidak beda jauh dengan indikator self contained $81.25 \%$. Untuk indikator self instruction dan stand alone memperoleh persentase $78 \%$ dan $62.5 \%$. Semua indikator dalam angket ahli materi ini berada dalam kategori valid.

\section{B. Self Instruction}

Banyak item untuk indikator Self Instruction adalah 25 item pernyataan yang diisi oleh validator ahli materi. Setelah data diperoleh didapatkan rata -rata skor 79 yang berada pada kategori Valid. Persentase jawaban untuk indikator dapat dilihat pada diagram Pie dibawah ini

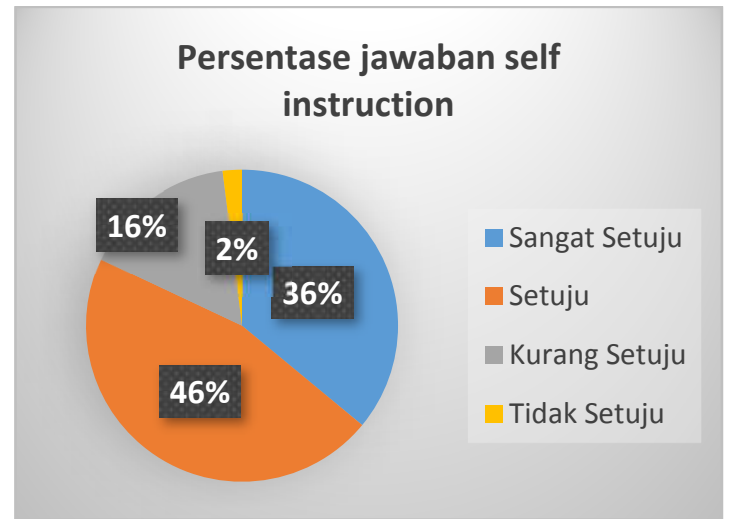

Gambar 2. Pie Diagram Persentase Jawaban Self Instruction

Pada diagram diatas $36 \%$ pernyataan dijawab dengan pilihan sangat setuju oleh validator ahli materi dan $46 \%$ adalah setuju. SubIndikator dari self insctruction adalah didapatkan dalam modul sudah tersedia instrument penilaian terbukti dengan persentasenya 100 , pengemasan materi modul adalah $88 \%$ dan tujuan pembelajaran sudah jelas yaitu $83 \%$ sedangkan yang lain sudah berada diatas $70 \%$. Lebih jelas dapat memperhatikan persentase nilai yang diperoleh.

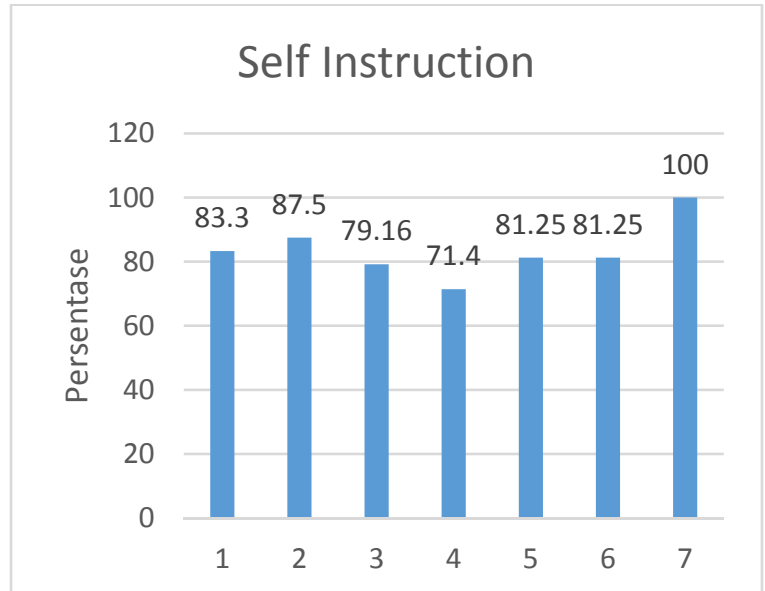

Gambar 3. Persentase Sub Indikator Self Instruction

Keterangan :

1. Kejelasan tujuan pembelajaran

2. Pengemasan materi pembelajaran

3. Materi pembelajaran didukung dengan contoh dan ilustrasi

4. Ketersediaan soal dan tugas untuk mengukur penguasaan

5. Penggunaan bahasa yang sederhana dan 
komunikatif

6. Ketersediaan instrument penilaian

\section{Self Contained}

Dalam indikator Self Containedi ini terdiri dari 2 item pernyataan dengan sib indikatornya memuat seluruh materi pembelajaran satu standar kompetensi sudah disajikan dengan baik terbukti dengan skor persentase yaitu $81.25 \%$. Rata -rata skor yang diperoleh dari validator ahli materi adalah 6.5 yang berada pada kategori valid. Sedangkan rata rata persentase skor adalah $75 \%$ dijawab setuju oleh validator. Untuk lebih jelas dapat memperhatikan diagram pie dibawah ini

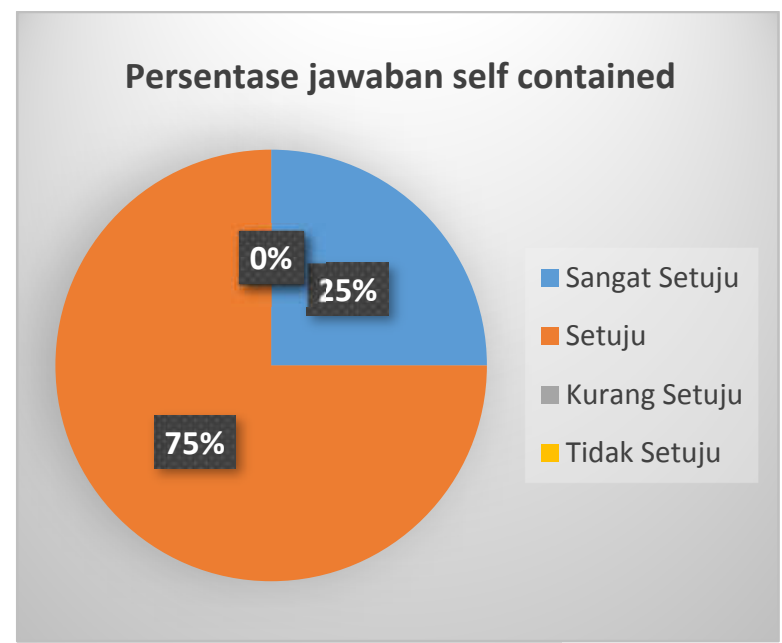

Gambar 4. Pie Diagram Persentase Jawaban Self Contained

\section{Stand Alone}

Hal yang sama dengan indikator Self Contained adalah pernyataan yang mewakili untuk indikator ini adalah 2 item dengan sub indikatornya adalah modul yang dibuat ini tidak bergantung pada bahan ajar lain sehingga mahasiswa tidak perlu lagi mencari bahan ajar lain untuk mendukung pembelajaran ini, skor persentase unutk sub indikator ini adalah $62.5 \%$ yaitu cukup baik. Rata -rata skor yang didapatkan adalah 5 yang berada kategori valid. Senada dengan persentase jawaban dari validator adalah $50 \%$ menjawab setuju dan setengahnya lagi menjawab kurang setuju. Untuk lebih jelas dapat dilihat pada digram pie dibawah ini

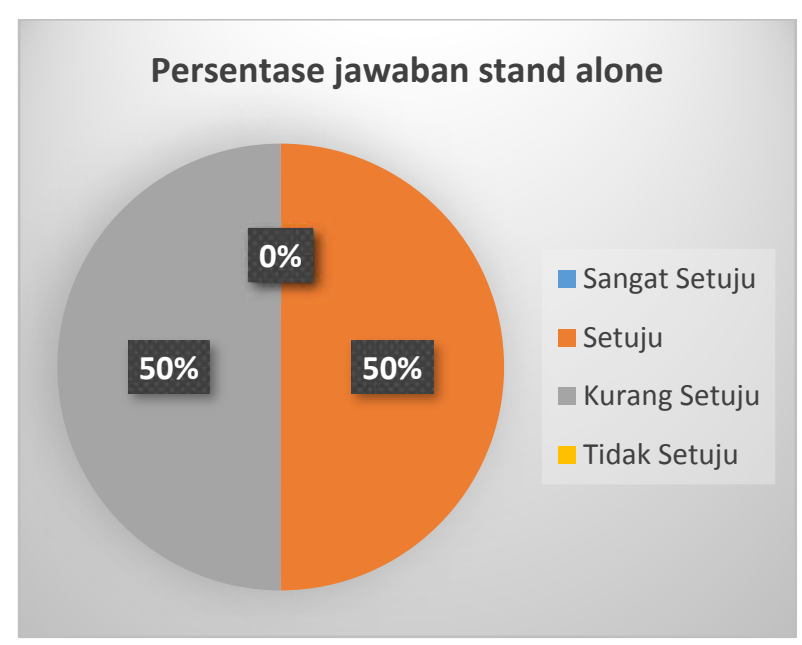

Gambar 5. Pie Diagram Persentase Jawaban Stand Alone

\section{E. Adaptif}

Dua item pernyataan dari indikator Adaptif memiliki rata rata skor 7 yang berada dalam kategori sangat valid. Persentase skor yang diperoleh adalah $87.5 \%$ yang berarti bahwa modul ini telah sesuai perkembangan ilmu pengetahuan dan teknologi serta fleksibel. Jika dilihat dari pilihan jawabannya adalah $50 \%$ setuju dan sangat setuju dan lebih jelas dapat memperhatikan pie diagram dibawah ini

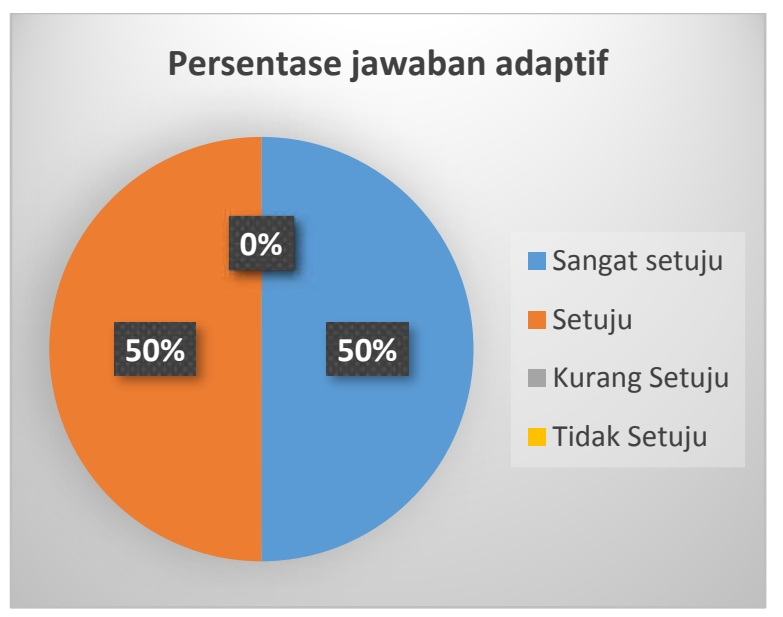

Gambar 6. Pie Diagram Persentase Jawaban Adaptif

\section{F. User Friendly}

Dalam indikator user friendly ini terdiri dari 4 item pernyataan yang merupakan instruksi dan informasi yang ada dalam modul mudah digunakan oleh pengguna yaitu mahasiswa. Rata -rata total skor yang diperoleh adalah 13.5 yang berada dalam ketegori valid dan persentase skor untuk indikator ini adalah $84.5 \%$. Jika dilihat dari persentase jawaban yang banyak dipilih adalah 
setuju yaitu $62.5 \%$.

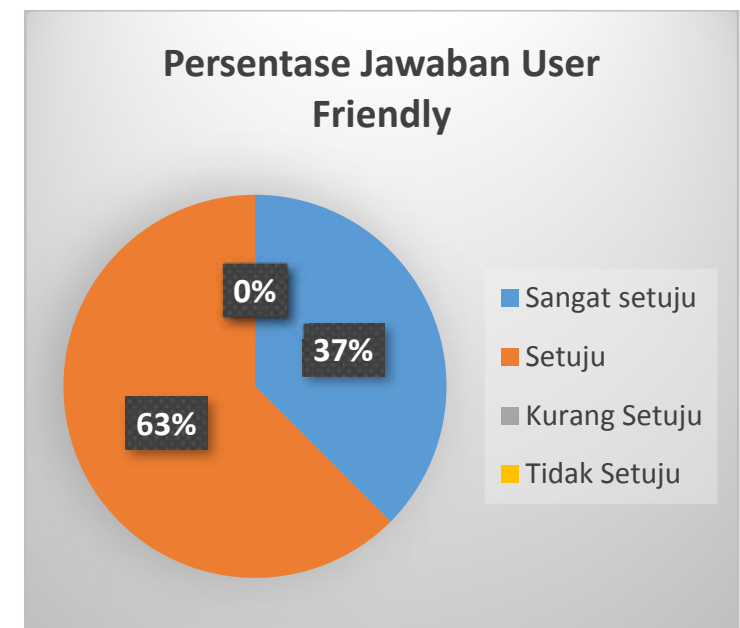

Gambar 7. Pie Diagram Persentase Jawaban User Friendly

\section{G. Analisis Data Ahli Media}

Modul pembelajaran merupakan sebuah bahan ajar cetak yang digunakan untuk pembelajaran, dengan kata lain modul pembelajaran adalah suatu media pembelajaran. Ahli media diperlukan untuk menguji/memberikan penilaian terhadap komponen media yang terdapat di dalam modul, untuk selanjutnya diberi penilaian valid atau tidak valid sebagai modul pembelajaran. Data hasil penilaian modul pembelajaran dikonversikan ke dalam interval skor skala lima Angket untuk ahli media terdapat 38 butir soal, maka dapat diketahui bahwa nilai skor maksimum adalah 152 , total skor minimum adalah 38 dengan simpangan baku ideal 19 Nilai tersebut jika dikonversikan ke dalam tabel sebuah tabel 2 kategori kelayakan hasilnya adalah sebagai berikut .

Tabel 4. Konversi Skor Rata Rata Untuk Ahli Media

\begin{tabular}{|l|l|l|}
\hline No & Rentangan Skor & Kategori \\
\hline 1 & $\mathrm{X}>110$ & $\begin{array}{l}\text { Sangat } \\
\text { Valid }\end{array}$ \\
\hline 2 & $87.4<\mathrm{X} \leq 110$ & Valid \\
\hline 3 & $64.6<\mathrm{X} \leq 87.4$ & $\begin{array}{l}\text { Cukup } \\
\text { Valid }\end{array}$ \\
\hline 4 & $41.8<\mathrm{X} \leq 64.6$ & Kurang \\
\hline 5 & $\mathrm{X} \leq 41.8$ & $\begin{array}{l}\text { Tidak } \\
\text { Valid }\end{array}$ \\
\hline
\end{tabular}

Dari tabel diatas, penilaian ahli media tentang modul pembelajaran berada dalam kategori sangat valid yaitu dengan rata rata total skor yang didapatkan yaitu 128. Dari tabel diatas, penilaian ahli media tentang modul pembelajaran berada dalam kategori sangat valid yaitu dengan rata rata total skor yang didapatkan yaitu 120. Penilaian ahli media meliputi indikator format, organisasi, daya tarik, bentuk dan ukuran huruf, ruang (spasi kosong), dan konsistensi. Data persentase setiap aspek dapat dilihat pada histogram dibawah ini.

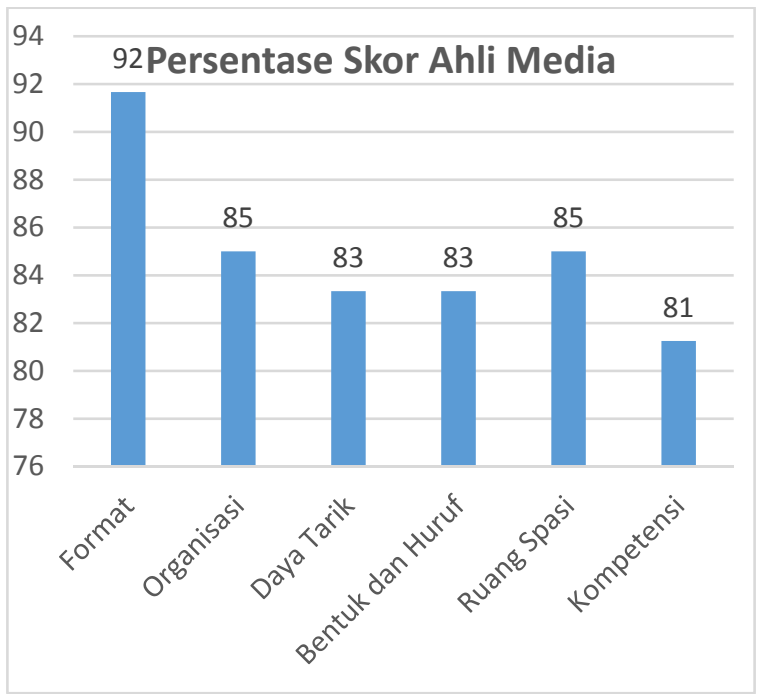

Gambar 8. Histogram Persentase Skor Ahli Media

Dari histogram diatas, terlihat bahwa pencapaian untuk setiap indikator memperoleh persentase diatas $80 \%$. Dimulai dari yang paling tinggi yaitu indikator format dengan persentase $92 \%$ kemudian persentase $85 \%$ diperoleh oleh indikator organisasi dan ruang spasi. Untuk persentase terendah diperoleh oleh indikator kompetensi.

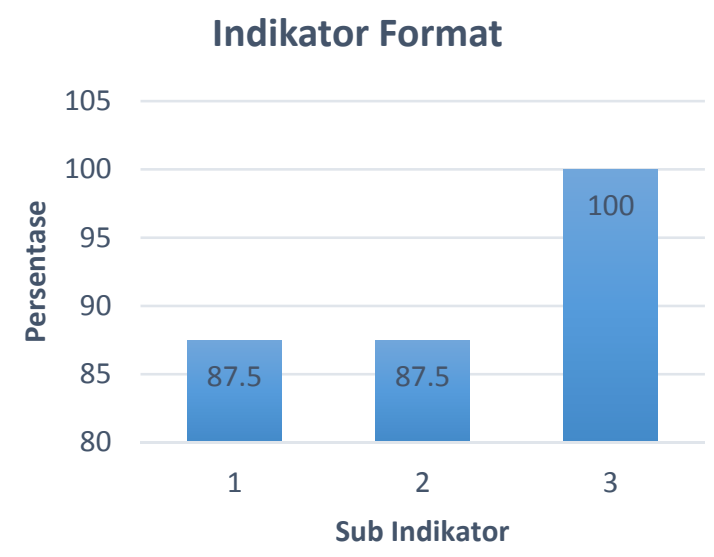

Gambar 9. Histogram Persentase subIndikator Format

Keterangan :

1. Format kolom

2. Format kertas

3. Penggunaan icon gambar 


\section{H. Format}

Pada indikator format memiliki 3 item pernyataan dengan subindikator yang berbeda yaitu format kolom yang ada modul sudah sangat baik, format kertas juga sangat baik dan penggunaan icon gambar yang ada pada modul adalah sempurna. Untuk lebih jelas dapat dilihat pada histogram dibawah ini.

Untuk total skor 11 yang berada pada kategori sangat valid. Sedangkan persentase jawaban $66.7 \%$ menjawab sangat setuju dan $33 \%$ menjawab setuju yang lebih jelas dapat memperhatikan pie diagram dibawah ini.

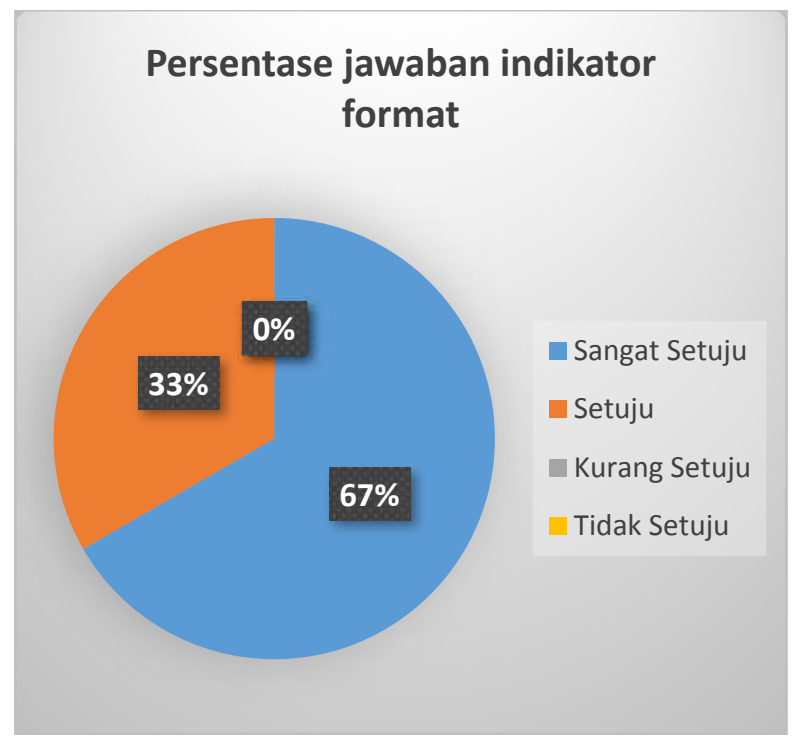

Gambar 10. Pie Diagram Persentase Jawaban Indikator Format

\section{Organisasi}

Dalam indikator organisasi memiliki 10 item pernyataan yang diwakili dengan beberapa sub indikator. Untuk kelengkapan modul yang telah dibuat sudah mencapai skor persentase $75 \%$, penggunaan bagan menggambarkan cakupan materi sudah sangat baik yaitu $87.5 \%$, sistematika dan penempan materi sudah sesuai termasuk alur antar bab yang berurutan. Untuk lebih jelas dapat memperhatikan histogram dibawah ini.

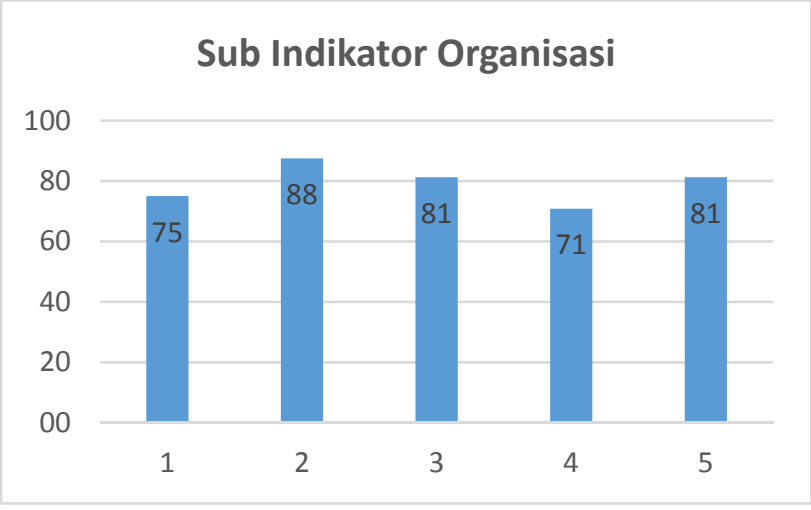

Gambar 11. Histogram Persentase Skor Sub Indikator Organsasi

Keterangan :

1. Kelengkapan bagian modul

2. Penggunaan peta/bagan yang menggambarkan cakupan materi

3. Sistematikan atau urutan materi

4. Penempatan naskah, gambar dan ilustrasi

5. Susunan dan alur bab, antar unit dan antar paragraf

Rata -rata skor yang diperoleh adalah 31.5 yang berada dalam kategori valid. Sedangkan persentase jawaban yang didapatkan adalah $65 \%$ menjawab setuju. Lebih jelas dapat memperhatikan pie diagram dibawah ini

\section{Persentase Jawaban organisasi}

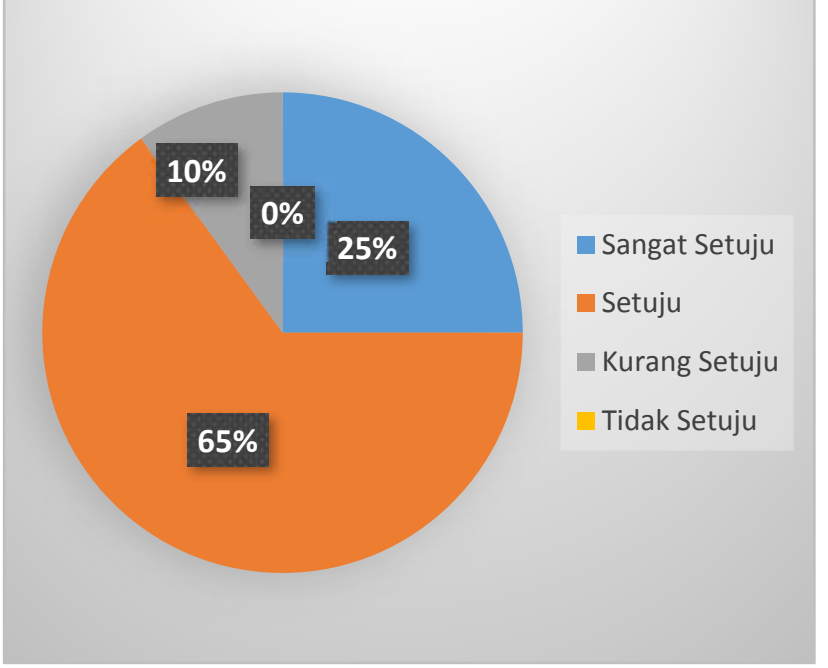

Gambar 9. Pie Diagram Persentase Jawaban

Organisasi.

\section{J. Daya Tarik}

Rata - rata skor yang diperoleh dari indikator daya tarik adalah 19 dari 6 item pernyataan yang 
dijawab oleh validator. Rata rata skor tersebut berada dalam kategori valid. Indikator daya tari terdiri dari 2 sub indikator yaitu keserasian kombinasi warna, gambar, bentuk ukuran huruf pada bagian cover mencapai skor $70 \%$, pengemasan gambar, pencetakan huruf tebal hingga garis bawah atau warna pada bagian isi modul sudah sangat baik dengan skor $87.5 \%$, dan yang terakhir pengemasan tugas dan latihan adalah $87.5 \%$. Untuk lebih jelas dapat dilihat pada histogram dibawah ini.

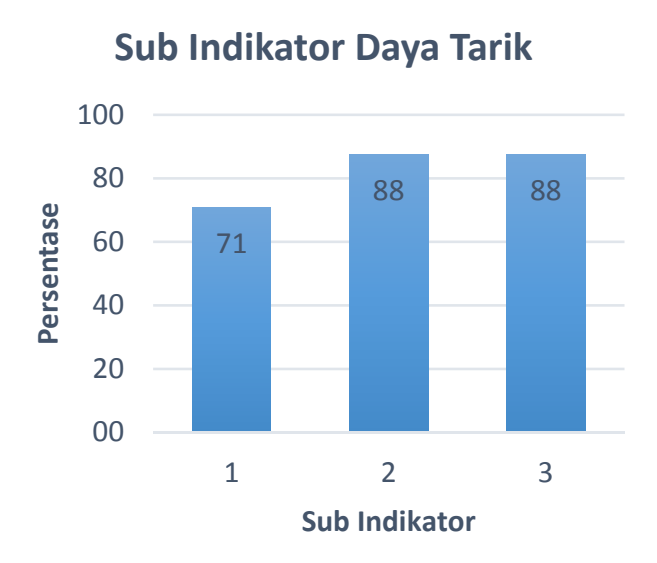

Gambar 12. Histogram SubIndikator Daya Tarik

Keterangan :

1. Keserasian kombinasi warna, gambar, bentuk dan ukuran huruf pada bagian cover

2. Pemberian gambar atau ilustrasi, pencetakan huruf tebal, miring, garis bawah atau warna pada bagian isi modul

3. Pengemasan tugas dan latihan

Untuk persentase jawaban adalah setuju sebanyak $66.7 \%$ dan $8.33 \%$ jawaban adalah kurang setuju. Untuk lebih jelas dapat memperhatikan pie diagram dibawah ini

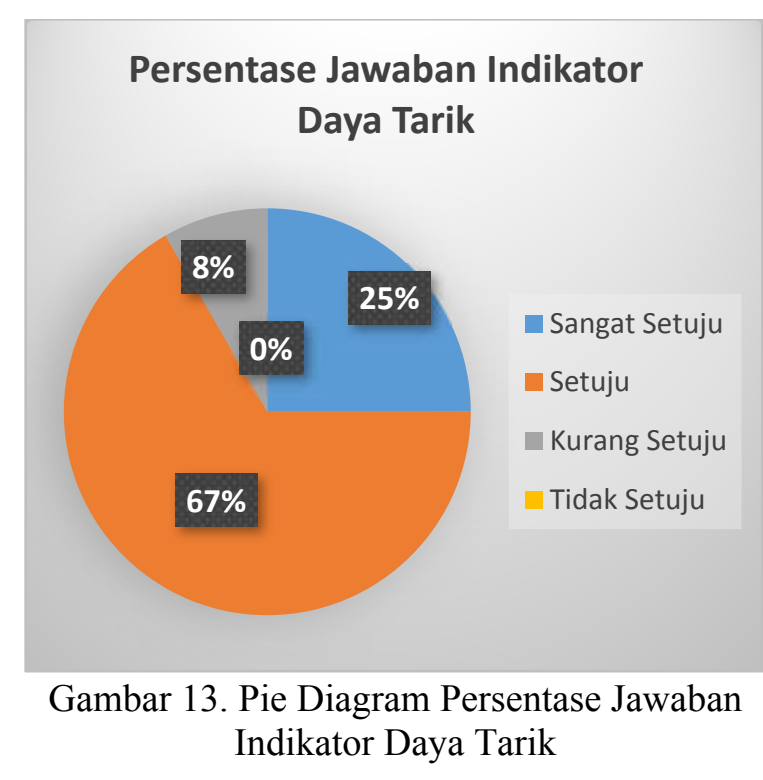

\section{K. Bentuk dan Huruf}

Untuk indikator bentuk dan huruf berada dalam kategori valid dengan rata rata skor yaitu 17.5. Dalam indikator ini terdiri dari 2 sub indikator yaitu kemudahan membaca bentuk dan ukuran huruf dengan skor persentase yaitu $75 \%$ sedangkan perbandingan huruf yang proporsional antar judul berada di skor $95.8 \%$ yang artinya sangat baik. Untuk lebih jelas dapat memperhatikan histogram dibawah ini.

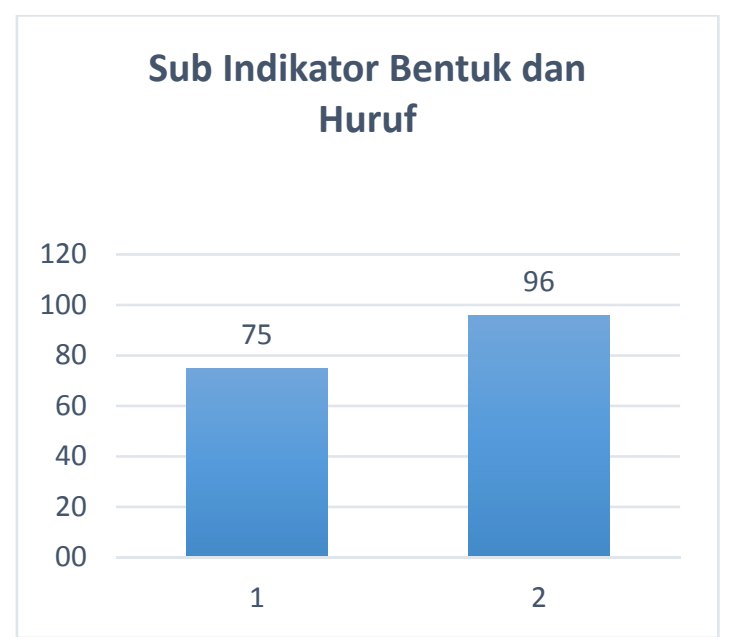

Gambar 14. Histogram Sub Indikator Bentuk Huruf.

1. Keterangan :

2. Kemudahan membaca bentuk dan ukuran huruf

3. Perbandingan huruf yang proporsional antar judul

Jika dilihat pada pie diagram dibawah ini $58.3 \%$ menjawab setuju. 


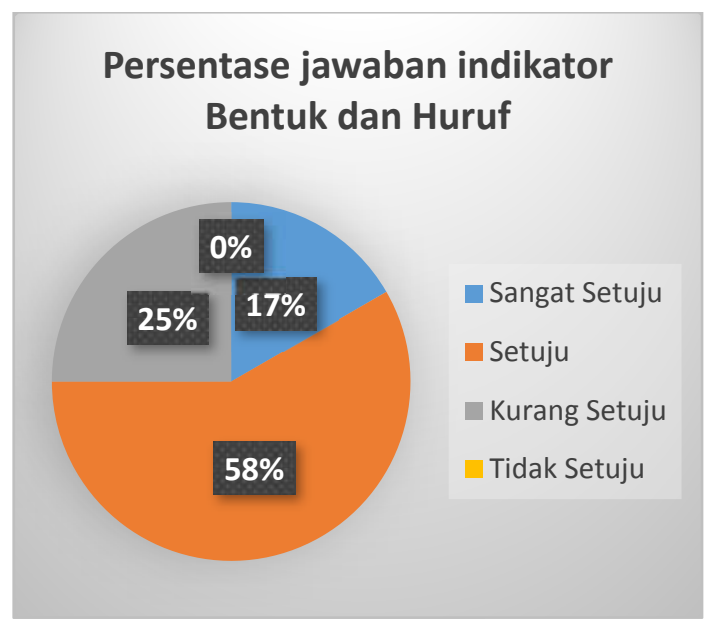

Gambar 15. Persentase Jawaban Indikator Bentuk dan Huruf

\section{Konsistensi}

Dalam indikator konsistensi memiliki 8 item pernyataan dengan sub indikator yaitu konsistensi bentuk dan huruf dari halaman ke halaman memiliki skor persentase $75 \%$ sama dengan konsistensi dalam spasi antar kalimat. Sedangkan tata letak pengetikan memiliki persentase yaitu $68.75 \%$. Untuk lebih jelas dapat memperhatikan histogram dibawah ini

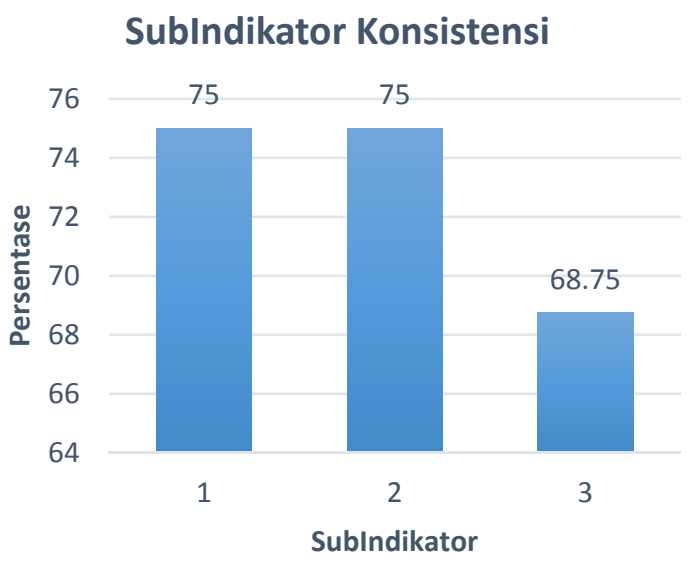

Gambar 16. Histogram Skor Persentase Sub Indikator Konsistensi

Keterangan :

1. Konsistensi bentuk dan huruf dari halaman ke halaman

2. Konsistensi spasi

3. Konsistensi tata letak pengetikan

Data yang telah didapatkan yaitu rata rata skor 23.5 berada dalam kategori valid. Persentase jawabannya yaitu $68.75 \%$ menjawab setuju dan sisanya tersebar dai pilihan jawaban sangat setuju dan kurang setuju.

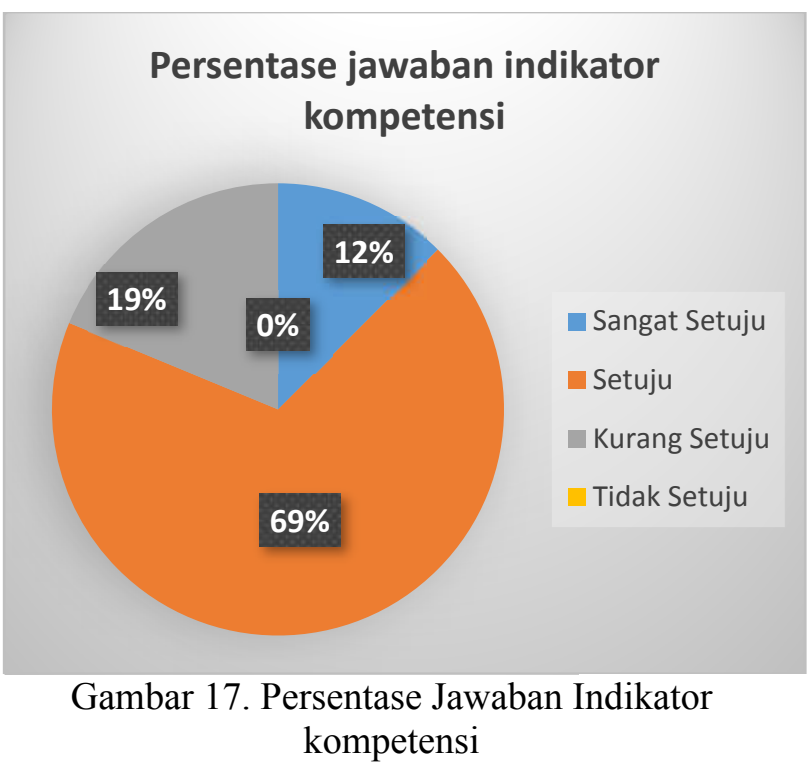

\section{KESIMPULAN}

Modul yang dikembangkan sudah valid untuk digunakan sebagai sumber belajar ditinjau dari aspek materi, aspek media, dan aspek sisi pengguna modul yaitu mahasiswa. Hasil uji validitas dan praktis modul sebagai berikut :

Dari ahli materi mendapatkan kategori valid dengan rata rata skor 111. persentase untuk masing masing aspek dari angket yang diberikan kepada ahli materi, Untuk indikator adaptif memperoleh persentase tertinggi yaitu $87.5 \%$, kemudian disusul oleh indikator user friendly memiliki persentase $84.375 \%$ yang tidak beda jauh dengan indikator self contained $81.25 \%$. Untuk indikator self instruction dan stand alone memperoleh persentase $78 \%$ dan $62.5 \%$. Semua indikator dalam angket ahli materi ini berada dalam kategori valid.

Dari ahli media mendapatkan kategori valid dengan rata rata skor 120 . terlihat bahwa pencapaian untuk setiap indikator memperoleh persentase diatas $80 \%$. Dimulai dari yang paling tinggi yaitu indikator format dengan persentase $92 \%$ kemudian persentase $85 \%$ diperoleh oleh indikator organisasi dan ruang spasi. Untuk persentase terendah diperoleh oleh indikator konsistensi. Dari semua indikator tersebut berada dalam kategori " valid". 


\section{DAFTAR PUSTAKa}

[1] I Wayan Santyasa , I Wayan Sukra Warphala, dan I Made Tegeh. (2015). Validasi dan Implementasi Model - Model Student Centered Learning Untuk Meningkatkan Penalaran dan Karakter Siswa Sekolah Menengah Atas. Jurnal Pendidikan Indonesia Vol 4, No 1, April 2015.

[2] Remon Lapisa, Irma Yulia Basri, dan dkk. (2017). Peningkatan Kompetensi Siswa Melalui Pelatihan AutoCAD. INVOTEK: Jurnal Inovasi, Vokasional dan Teknologi, Vol 17, No 2, Oktober 2017.

[3] A Rachman, NE Raharjo.( 2017). Pengembangan Media Pembelajaran Video Tutorial Dynamic Block dalam AutoCad pada Mata Pelajaran Menggambar Dengan Perangkat Lunak Kelas XII SMKN 1 Pajangan. E- Journal Pend Teknik Sipil- journal. Student.uny.ac.id.

[4] Martubi dan Amir Fatah. (2010). Peningkatan Prestasi Belajar CAD Mahasiswa Teknik Otomotif Non -Reguler FT UNY Melalui Pembuatan "Pohon Kata" Perintah Dalam Program AutoCAD. JPTK, Vol 19 No 1, Mei 2010.

[5] Abdul Majid. (2012). Perencanaan Pembelajaran Pengembangan Standar Kompetensi dosen. Bandung: PT.Remaja rosdakarya.

[6] Daryanto. (2013). Menyusun Modul (Bahan Ajar untuk Persiapan Dosen dalam Mengajar). Yogyakarta: PT Gava Media.

[7] Rona Taula Sari. (2017). Uji Validitas Modul Pembelajaran Biologi Pada Materi Sistem Reproduksi Manusia Pendekatan Konstruktivisme Untuk Kelas IX SMP. Scientiae Educatia : Jurnal Pendidikan Sains Vol 6 (1) : $22-26$.

[8] Suharsimi Arikunto.(2012). Dasar-dasar evaluasi pendidikan. Jakarta: Bumi Aksara
[9] Komang Setemen. (2018). Pengembangan dan Pengujian Validitas Butir Instrumen Kecerdasan Logis - Matematis. Jurnal Pendidikan Teknologi dan Kejuruan Vol 15. No 2. Juli 2018 Hal 178.

[10] Sugiyono. (2011). Metode Penelitian Kuantitatif Kualitatif dan R\&D. Bandung. Penerbit: Alfabeta

[11] Riduwan. 2011. Belajar Mudah Penelitian Untuk Guru, Karyawan, dan Peneliti Pemula. Bandung: Alfabeta

\section{Biodata Penulis}

Hamdani, lahir di Batusangkar, 6 Juni 1988. Tahun 2014 memperoleh gelar Magister Pendidikan Teknologi dan Kejuruan dari Universitas Negeri Padang dengan bidang konsentrasi Pendidikan Teknik Elektro. Tahun 2015 hingga sekarang adalah staf pengajar di Jurusan Teknik Elektro Fakultas Teknik Universitas Negeri Padang.

Doni Tri Putra Yanto, lahir di cupak 16 April 1993. Tahun 2016 memperoleh gelar Magister Pendidikan Teknologi dan Kejuruan dengan konsentrasi Pendidikan Teknik Elektro dari Magister Fakultas Teknik Universitas Negeri Padang. Kemudian mulai dari tahun 2017 menjadi staf pengajar di Jurusan Teknik Elektro FT UNP hingga sekarang.

Ricky Maulana, lahir di Solok 15 Oktober 1989. Tahun 2015 memperoleh gelar Magister Teknik dengan bidang ilmu Teknik Elektro dari Institut Teknologi Bandung. Menjadi staf pengajar di Jurusan Teknik Elektro mulai dari tahun 2017 hingga sekarang. 